\title{
Optimizing concentrations and contact times of cleaning and sanitizing agents for inactivating winery spoilage microorganisms
}

\author{
C. Marx and A. Oberholster \\ Department of Viticulture and Enology, University of California, 945616 Davis, USA
}

\begin{abstract}
Microbial management is one of the most critical aspects of winery operations and is normally achieved via chemical control. This study sought to optimize winery cleaning and sanitation protocols for the management of winery spoilage microorganisms by applying multiple techniques commonly found in clinical health settings to winery-relevant conditions. The minimum inhibitory concentration and minimum biocidal concentration assay and a modified minimum biofilm inactivation assay were performed for three common winery spoilage yeast (S. cerevisiae, B. bruxellensis, Z. baili). Results indicate that inhibitory and biocidal concentrations vary dramatically between organisms but are largely in line with established application rates for inactivation of all cells in planktonic and biofilm physiologies. Dual-channel fluorescence staining was employed to determine minimum inactivation time for $S$. cerevisiae using two peracetic acid concentrations. Propidium Iodide and SYBR Green 1 stains were validated as a live/dead proxy $\left(\mathrm{R}^{2}=0.99\right)$ and used to determine the contact time required to inactivate cell suspensions. Peracetic acid treatment trials indicate that $S$. cerevisiae populations are inactivated in five minutes or less at concentrations of $1-1.5 \mathrm{mg} / \mathrm{L}$. In conjunction, these experiments provide insight for winemakers to critically think about cleaning and sanitation protocols and how to optimize these processes.
\end{abstract}

\section{Introduction}

Microbial control is of paramount importance in wineries. Product quality and salability directly depend on a winemaker's ability to proactively prevent contamination from spoilage microorganisms during cleaning and sanitation operations [1]. Winery workers invest significant quantities of time and resources during harvest cleaning and sanitizing winery surfaces and components, but processes are far from standardized or optimized. Wineries must therefore independently determine the cleaning and sanitizing products to use, the protocol by which these products are used, and a means for determining the efficacy of cleaning and sanitizing operations.

Cleaning and sanitizing agents traditionally used in wineries include sulfur dioxide, citric acid, caustic soda, and halogenated compounds, all of which pose an environmental threat and financial burden for treatment [2]. With an increasing need for environmentally sustainable operations a new generation of environmentally friendly cleaning and sanitizing agents is appearing on the market. Common examples of chemical agents in this category are based on peracetic acid and hydrogen peroxide, often with added surfactants and chelating agents. A sanitizing scheme based on a paired potassium buffer system that can be reclaimed for reuse via filtration has also been proposed [3]. Several studies have been conducted on the comparative efficacy of winery cleaning and sanitizing agents [4-6], however none of these efforts fully explore the minimization of chemical inputs across a comprehensive set of chemistries for winery yeast.

Zygosaccharomyces baili, Brettanomyces bruxellensis, and unwanted Saccharomyces cerevisiae populations are commonly responsible for winery spoilage [7]. Of special concern are spoilage organisms existing as biofilms, surface-associated aggregates commonly reported to exhibit increased resistance to antimicrobial agents [8]. Recommended application rates for chemical control of these organisms varies greatly between sources, and often recommendations are based on results for organisms such as E. coli, Listeria, or Salmonella, which are not relevant in wine production settings [3]. This experiment assesses the validity of these recommendations for winery relevant conditions for a suite of cleaning and sanitizing chemicals using the minimum inhibitory concentration/minimum biocidal concentration (MIC/MBC) assay and dual-channel fluorescence microscopy. While cleaning and sanitation are separate processes, here the effectiveness of agents marketed for cleaning or sanitation purposes is measured in terms of microbial inactivation only.

The MIC/MBC assay is a well-established method for determining the minimum concentration of an antimicrobial agent required to inhibit or inactivate microorganisms [9]. Microbial suspensions are exposed to serial dilutions of antimicrobial agents in microtiter plates and allowed to incubate overnight, after which a sample is collected on nutrient agar and the absorbance of 
Table 1. Details of yeast species used in experiment.

\begin{tabular}{|ccccc|}
\hline Organism & UC Davis VEN ID & Source & Origin & Year Isolated \\
\hline Saccharomyces cerevisiae EC 1118 & 777 & Commercially available dry yeast & France & 1984 \\
Brettanomyces bruxellensis & 2041 & Star fruit wine & Thailand & 2002 \\
Zygosaccharomyces baili & 858 & Commercial wine & California & 1989 \\
\hline
\end{tabular}

the microtiter plate is read to assess in-situ cell growth. From these results it is possible to determine the minimum chemical concentration required for microbial inactivation (inability to culture) or inhibition (prevention of in-situ growth). Advantages of this method include simplicity, ease of reproducibility, and the ability to perform highthroughput analysis of numerous antimicrobial agents with limited raw materials. While this method has been applied to Saccharomyces cerevisiae [10], the MIC/MBC assay has never been applied in a winemaking context for any spoilage yeast. The MIC/MBC assay is an ideal method for cross-comparing chemical efficiency and will be used here to examine whether effective treatments can be applied below manufacturer's recommended chemical concentrations.

Dual-channel yeast fluorescence microscopy is a powerful tool for staining cellular components to observe changes in a population [11]. A common application involves the use of propidium iodide (PI) red fluorescent protein (RFP), which is excreted by viable cells, but retained in inactivated cells. When used in conjunction with a green fluorescent protein (GFP) that stains all cells regardless of viability, a proxy system is developed for assessing cell viability in a population. Numerous protocols and commercial kits that leverage this system are available, and the technique has been successfully applied to Saccharomyces cerevisiae [12]. As with the MIC/MBC assay, the technique has yet to be applied to winemaking conditions. This experiment first validates an established RFP/GFP protocol as a proxy for cellular viability, and then uses the protocol to determine the minimum contact time required for the inactivation of $S$. cerevisiae with multiple concentrations of peracetic acid.

In this project, the MIC/MBC assay is used to identify minimum concentrations of a suite of cleaning and sanitizing agents required to inhibit or inactivate three spoilage yeasts, respectively. The assay is modified and extended to determine the minimum concentration required to inactivate cells immobilized in a biofilm structure. Dual-channel fluorescence using propidium iodide (RFP) and SYBR Green 1 (GFP) is validated as a proxy for cellular viability and used to determine the contact time necessary for inactivation of $S$. cerevisiae with two concentrations of peracetic acid. We hypothesize that the applied chemicals will be effective at concentrations below manufacturer's suggested rates, and the combination of the MIC/MBC method and fluorescence will allow for the optimization of peracetic acid sanitation of Saccharomyces cerevisae, with the potential to be expanded to other winery bacteria and yeast. This experiment applies two methodologies to the study of winery-relevant conditions for the first time and will provide a method for optimizing the use of chemical agents for cleaning and sanitation.

\section{Materials and methods}

\subsection{Yeast cultures, broth, and $50 \%$ grape juice medium}

Yeast culture stocks were obtained from the University of California, Davis Viticulture and Enology Culture Collection and supplied on nutrient agar plates. Yeast species are detailed in Table 1.

Yeast-mold (YM) broth (BD Difco, New Jersey USA) and a sterile $50 \%$ grape juice medium were used as culture media. YM broth was prepared according to manufacturer's instructions and autoclaved to sterilize. To prepare the grape juice medium Chardonnay grapes were harvested fresh from the University of California, Davis Tyree vineyard at $25^{\circ}$ Brix and directly pressed. The juice was centrifuged at $4500 \times \mathrm{g}$ for 10 minutes (Sorvall RC 5B Plus, Massachusetts USA), filtered to $0.22 \mu \mathrm{m}$ (Corning \#431118, Massachusetts USA), and diluted to 50\% with sterile-filtered water. Yeast-mold agar was prepared by adding $15 \mathrm{~g} / \mathrm{L}$ agar (BD Difco, New Jersey, USA) to the YM broth formulation prior to autoclaving.

\subsection{Winery chemicals}

Cleaning and sanitizing chemicals were prepared within 30 minutes of use according to manufacturer's instructions in sterile deionized water. A $50 \%$ dilution scheme is used in the MIC/MBC assay. Chemical species and maximum concentrations are detailed in Table 2. Several proprietary formulations were tested and are indicated where applicable.

\section{3. $M I C / M B C$ and biofilm assay}

Protocol adapted from CLSI, 2008 and Wiegand et al., 2008 [9,14]. Separate 96-well microtiter plates were prepared for microbe inoculum and challenge chemicals. Microbe inoculum $\left(0.5 \mathrm{OD}_{600 \mathrm{~nm}}\right)$ was prepared in $\mathrm{YM}$ broth and $50 \%$ grape juice medium, respectively, as measured by spectrophotometer (Shimadzu UV-1800, Kyoto Japan). Inoculum $(200 \mu \mathrm{L})$ was plated in each well of a 96-well microtiter plate. Challenge chemicals were prepared fresh at double the final test concentration for each trial. Four hundred microliters of the maximum concentration of each chemical was prepared in the first row of the microtiter plate and $200 \mu \mathrm{L}$ of $1 / 8 \mathrm{X}$ phosphatebuffered saline (PBS) (10X Dry Pack \# 20-134, Apex Chemicals and Reagents, Bangkok Thailand) was plated in all other wells. Dilutions were performed by mixing $200 \mu \mathrm{L}$ from the first row into the $1 / 8 \mathrm{X}$ phosphate-buffered 
Table 2. Chemicals used in MIC/MBC assay. *denotes pre-measured proprietary liquid.

\begin{tabular}{|c|c|c|c|}
\hline Chemical & Source & Maximum applied concentration & Manufacturer's Recommended Concentration \\
\hline Sodium Hydroxide $(\mathrm{NaOH})$ & Fisher Scientific (NH, USA; ACS grade, 98.9\%, CAS\# 1310-73-2) & $80 \mathrm{~g} / \mathrm{L}$ & $10-20 \mathrm{~g} / \mathrm{L}$ \\
\hline Sodium Hydroxide Blend & Proprietary Formulation $(40-45 \% \mathrm{NaOH})$ & $80 \mathrm{~g} / \mathrm{L}$ & $10-20 \mathrm{~g} / \mathrm{L}$ \\
\hline Potassium Hydroxide, $(\mathrm{KOH})$ & Sigma-Aldrich (MO, USA; ACS grade, $\geq 85 \%$, CAS\# 1310-58-3) & $80 \mathrm{~g} / \mathrm{L}$ & $10-20 \mathrm{~g} / \mathrm{L}$ \\
\hline Potassium Hydroxide Blend & Proprietary Formulation $(85-95 \% \mathrm{KOH})$ & $80 \mathrm{~g} / \mathrm{L}$ & $10-20 \mathrm{~g} / \mathrm{L}$ \\
\hline $\begin{array}{l}\text { EDTA/carbonate/QUAT/peroxide } \\
\text { blend }\end{array}$ & $\begin{array}{c}\text { Proprietary formulation ( } 6 \% \text { each } \mathrm{Na} \text { and } \mathrm{K} \text { carbonate, } 4.9 \% \\
\text { EDTA; cleaner: } 6 \% \text { alkyl dimethyl alkylbenzyl ammonium } \\
\text { chlorides, } 6.3 \% \mathrm{H} 2 \mathrm{O} 2 \text { ) }\end{array}$ & $50 \%(v / v)^{*}$ & $17 \%(v / v)^{*}$ \\
\hline Peracetic Acid & Acros Organics (NH, USA; 35\%, CAS\# 79-21-0) & $0.8 \mathrm{~g} / \mathrm{L}$ & $0.1-0.2 \mathrm{~g} / \mathrm{L}$ \\
\hline Hydrogen Peroxide, $\mathrm{H}_{2} \mathrm{O}_{2}$ & EMD Millipore (MA, USA; ACS grade, 29-32\%, CAS\# 7722-84-1) & $90.4 \mathrm{~g} / \mathrm{L}$ & $11.3-33.9 \mathrm{~g} / \mathrm{L}$ \\
\hline Potassium bisulfate & Fisher Scientific (NH, USA; Certified Crystalline, CAS\# 7646-93-7) & $10.89 \mathrm{~g} / \mathrm{L}$ & $2.72 \mathrm{~g} / \mathrm{L}$ \\
\hline $\begin{array}{c}\text { Potassium bisulfate }\left(\mathrm{KHSO}_{4}\right)+ \\
\text { Hydrogen Peroxide }\left(\mathrm{H}_{2} \mathrm{O}_{2}\right)\end{array}$ & See components above & $5.44 \mathrm{~g} / \mathrm{L}\left(\mathrm{KHSO}_{4}\right)+45.2 \mathrm{~g} / \mathrm{L}\left(\mathrm{H}_{2} \mathrm{O}_{2}\right)$ & $2.72 \mathrm{~g} / \mathrm{L}\left(\mathrm{KHSO}_{4}\right)+11.3 \mathrm{~g} / \mathrm{L}\left(\mathrm{H}_{2} \mathrm{O}_{2}\right)$ \\
\hline Chlorine Dioxide & Selective Micro Technologies (OH, USA; $500 \mathrm{ppm} \mathrm{ClO}_{2}$ stock) & $0.25 \mathrm{~g} / \mathrm{L}$ & $0.1-0.2 \mathrm{~g} / \mathrm{L}$ \\
\hline
\end{tabular}

Table 3. Dilution scheme used in MIC/MBC assay. Each entry represents a corresponding well in 96-well microtiter plate.

\begin{tabular}{|c|c|c|c|c|c|c|c|c|c|c|c|}
\hline $\mathrm{NaOH}(\mathrm{g} / \mathrm{L})$ & NaOH-blend $(g / L)$ & КОН $(\mathrm{g} / \mathrm{L})$ & $\underset{(\mathrm{g} / \mathrm{L})}{\text { KOH-blend }}$ & $\begin{array}{c}\text { Na- K- Carbonate blend, } \\
\text { EDTA (\%) }\end{array}$ & $\begin{array}{c}\text { Peracetic Acid } \\
(\mathrm{g} / \mathrm{L})\end{array}$ & $\begin{array}{c}\mathrm{H2O2} \\
(\mathrm{g} / \mathrm{L})\end{array}$ & $\underset{(\mathrm{g} / \mathrm{L})}{\mathrm{KHSO} 4}$ & $\underset{(\mathrm{g} / \mathrm{L})}{\mathrm{KHSO}+\mathrm{H}_{2} \mathrm{O} 2}$ & $\mathrm{ClO} 2(\mathrm{~g} / \mathrm{L})$ & $\begin{array}{l}\text { growth } \\
\text { check }\end{array}$ & sterility check \\
\hline 80.00 & 80.00 & 80.00 & 80.00 & 0.500 & 0.800 & 90.40 & 10.890 & $5.45+45.20$ & 0.2500 & & \\
\hline 40.00 & 40.00 & 40.00 & 40.00 & 0.250 & 0.400 & 45.20 & 5.445 & $2.723+22.60$ & 0.1250 & 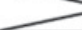 & \\
\hline 20.00 & 20.00 & 20.00 & 20.00 & 0.125 & 0.200 & 22.60 & 2.723 & $1.361+11.30$ & 0.0625 & 1 & 1 \\
\hline 10.00 & 10.00 & 10.00 & 10.00 & 0.063 & 0.100 & 11.30 & 1.361 & $0.681+5.65$ & 0.0313 & 2 & 2 \\
\hline 5.00 & 5.00 & 5.00 & 5.00 & 0.031 & 0.050 & 5.65 & 0.681 & $0.340+2.83$ & 0.0156 & 3 & 3 \\
\hline 2.50 & 2.50 & 2.50 & 2.50 & 0.016 & 0.025 & 2.83 & 0.340 & $0.170+1.41$ & 0.0078 & 4 & 4 \\
\hline 1.25 & 1.25 & 1.25 & 1.25 & 0.008 & 0.013 & 1.41 & 0.170 & $0.085+0.71$ & 0.0039 & 5 & 5 \\
\hline 0.63 & 0.63 & 0.63 & 0.63 & 0.004 & 0.006 & 0.71 & 0.085 & $0.043+0.353$ & 0.0020 & 6 & 6 \\
\hline
\end{tabular}

saline in the row below, mixing via pipette, and repeating until $400 \mu \mathrm{L}$ of the lowest concentration remains in the last row with all wells thoroughly mixed. Two hundred microliters from each well of the challenge chemical plate was transferred into corresponding wells in inoculated microtiter plates, resulting in $400 \mu \mathrm{L}$ final volume at test concentration. Details for the final dilution scheme are given in Table 3. Growth check and sterility check wells were included for quality assurance. Plates were incubated for 24 hours at $30^{\circ} \mathrm{C}$. Each well was sampled $(10 \mu \mathrm{L})$ onto nutrient agar and the absorbance of the plates was measured via plate reader at $600 \mathrm{~nm}$ (Synergy Neo 2, Biotek Instruments, Inc, Vermont USA). Sample agar plates were incubated for three weeks at $30{ }^{\circ} \mathrm{C}$ to facilitate growth of less-rapidly dividing cells.

A modified form of the MIC/MBC analysis was developed to assess the efficacy of challenge chemicals in inactivating sessile yeast populations. Biofilms were formed in 96-well microtiter plates according to the method described in Joseph, Kumar, and Bisson, 2007 [13] in 50\% grape juice medium. The supernatant was aspirated, and biofilms were washed with 1/8X PBS three times to remove residual growth medium. To conduct a trial, $200 \mu \mathrm{L}$ of challenge chemical was plated in corresponding wells of the biofilm plate and allowed to sit for 24 hours at room temperature. Wells were rinsed three times with $1 / 8 \mathrm{X}$ PBS to remove chemical residue. Two hundred microliters of 1/8X PBS was added to each well and the plates were sonicated for 30 seconds to release the biofilm from the microtiter plate surface before plating $10 \mu \mathrm{L}$ from each well onto nutrient agar. Plates were incubated for three weeks at $30^{\circ} \mathrm{C}$ for growth and measured by plate reader at $600 \mathrm{~nm}$.

\subsection{SYBR Green 1 / PI fluorescent staining}

Stain protocol adapted from method described in adapted from Feng, Wang, Zhang, Shi, \& Zhang, 2014 [15]. An ethanol kill curve was developed by mixing prepared stocks of live and dead Saccharomyces at standard proportions. A microbe broth with absorbance of 0.5 $\mathrm{OD}_{600 \mathrm{~nm}}$ was developed in $50 \%$ grape juice medium. The prepared dead microbe stock cells were centrifuged and resuspended to $0.5 \mathrm{OD}_{600 \mathrm{~nm}}$ in $70 \%$ ethanol (KOPTEC 190 proof, USP specifications, 95\%, cat\# V1101). After 30 minutes cells were centrifuged, washed three times with $0.85 \%$ sodium chloride $(\mathrm{NaCl})$, and re-suspended to $0.5 \mathrm{OD}_{600 \mathrm{~nm}}$ in $0.85 \% \mathrm{NaCl}$. Live microbe stock was prepared by centrifuging the microbe broth, washing with $0.85 \% \mathrm{NaCl}$ and resuspending to $0.5 \mathrm{OD}_{600 \mathrm{~nm}}$ in $0.85 \% \mathrm{NaCl}$. The live and dead microbe stocks were mixed at $20 \%$ intervals from $100 \%$ alive to $0 \%$ alive stock. Fluorescent dye stock was prepared fresh for each trial and kept protected from light. Fluorescent stock was prepared by adding $10 \mu \mathrm{l}$ SYBR Green I $(10,000 \times$ stock, Invitrogen) and $0.2 \mathrm{mg}$ propidium iodide (Arcos Organics, 95\% CAS\# 25535-16-4) to a final volume of $10 \mathrm{~mL}$ in $0.85 \% \mathrm{NaCl}$. Each blended stock $(180 \mu \mathrm{L})$ was plated in a 96-well microtiter plate in triplicate. Twenty microliters of stain stock was added to each well. Stained microtiter plates were placed on a shaker table (New Brunswick Innova 26R, Hamburg Germany) and allowed to develop for $30 \mathrm{~min}$ at $200 \mathrm{rpm}$ and $25^{\circ} \mathrm{C}$ before using a fluorescence microplate reader set to dual-channel mode.

Peracetic acid time-kill trials were conducted by mixing $20 \mathrm{~mL}$ of $0.5 \mathrm{OD}_{600 \mathrm{~nm}}$ microbe inoculum with $5 \mathrm{~mL}$ peracetic acid solution, vortexing for five seconds, and quenching into $225 \mathrm{~mL}$ solution containing $0.85 \%$ $\mathrm{NaCl}$ and $1 \%$ fetal bovine serum (FBS) to halt cell damage. Cells were centrifuged and re-suspended to $0.5 \mathrm{OD}_{600 \mathrm{~nm}}$. One hundred eighty microliters microbe inoculum at each contact time was plated into a microtiter plate, in triplicate. Tests were conducted using peracetic acid at $0.1 \mathrm{~g} / \mathrm{L}$ and $0.15 \mathrm{~g} / \mathrm{L}$. A zero-contact time was simulated by mixing 
Table 4. Results for MIC/MBC and biofilm assay. Reference concentrations included at bottom for comparison.

\begin{tabular}{|c|c|c|c|c|c|c|c|c|c|c|c|c|}
\hline Organism & Medium & Indicator & $\mathrm{NaOH}$ & $\begin{array}{c}\mathrm{NaOH}- \\
\text { blend }\end{array}$ & КОН & KOH-blend & $\begin{array}{c}\text { Na- K-Carbonate } \\
\text { blend, QUAT, } \\
\text { EDTA }\end{array}$ & $\begin{array}{c}\text { Peracetic } \\
\text { Acid }\end{array}$ & $\mathrm{H} 2 \mathrm{O} 2$ & KHSO4 & $\mathrm{KHSO} 4+\mathrm{H}_{2} \mathrm{O} 2$ & $\mathrm{CO}_{2}$ \\
\hline \multirow{4}{*}{ S. cerevisiae } & Broth & $\begin{array}{l}\text { MIC } \\
\text { MBC }\end{array}$ & $\begin{array}{l}1.25 \mathrm{~g} / \mathrm{L} \\
5 \mathrm{~g} / \mathrm{L}\end{array}$ & $\begin{array}{l}1.25 \mathrm{~g} / \mathrm{L} \\
5 \mathrm{~g} / \mathrm{L}\end{array}$ & $\begin{array}{l}1.25 \mathrm{~g} / \mathrm{L} \\
5 \mathrm{~g} / \mathrm{L}\end{array}$ & $\begin{array}{c}\leq 0.625 \mathrm{~g} / \mathrm{L} \\
2.5 \mathrm{~g} / \mathrm{L}\end{array}$ & $\begin{array}{c}\leq 0.0039 \% \\
1.560 \%\end{array}$ & $\begin{array}{l}0.013 \mathrm{~g} / \mathrm{L} \\
0.05 \mathrm{~g} / \mathrm{L}\end{array}$ & $\begin{array}{l}\leq 0.71 \mathrm{~g} / \mathrm{L} \\
\leq 0.71 \mathrm{~g} / \mathrm{L}\end{array}$ & $\begin{array}{l}0.681 \mathrm{~g} / \mathrm{L} \\
5.44 \mathrm{~g} / \mathrm{L}\end{array}$ & $\begin{array}{l}\leq 0.043 \mathrm{~g} / \mathrm{L}+0.353 \mathrm{~g} / \mathrm{L} \\
\leq 0.043 \mathrm{~g} / \mathrm{L}+0.353 \mathrm{gL}\end{array}$ & $\begin{array}{l}0.063 \mathrm{~g} / \mathrm{L} \\
1.25 \mathrm{mg} /\end{array}$ \\
\hline & \multirow{3}{*}{ Grape Juice } & MIC & $2.50 \mathrm{~g} / \mathrm{L}$ & $5 \mathrm{~g} / \mathrm{L}$ & $2.5 \mathrm{~g} / \mathrm{L}$ & $2.50 \mathrm{~g} / \mathrm{L}$ & $\leq 0.0039 \%$ & $0.05 \mathrm{~g} / \mathrm{L}$ & $\leq 0.71 \mathrm{~g} / \mathrm{L}$ & $0.681 \mathrm{~g} / \mathrm{L}$ & $\leq 0.043 \mathrm{~g} / \mathrm{L}+0.353 \mathrm{~g} / \mathrm{L}$ & $0.063 \mathrm{~g} / \mathrm{L}$ \\
\hline & & MBC & $10 \mathrm{~g} / \mathrm{L}$ & $20 \mathrm{~g} / \mathrm{L}$ & $20 \mathrm{~g} / \mathrm{L}$ & $10 \mathrm{~g} / \mathrm{L}$ & $\leq 0.0039 \%$ & $0.1 \mathrm{~g} / \mathrm{L}$ & $\leq 0.71 \mathrm{~g} / \mathrm{L}$ & $10.89 \mathrm{~g} / \mathrm{L}$ & $\leq 0.043 \mathrm{~g} / \mathrm{L}+0.353 \mathrm{~g} / \mathrm{L}$ & $1.25 \mathrm{mg} / \mathrm{L}$ \\
\hline & & Biofilm & $20 \mathrm{~g} / \mathrm{L}$ & $2.5 \mathrm{~g} / \mathrm{L}$ & $10 \mathrm{~g} / \mathrm{L}$ & $5 \mathrm{~g} / \mathrm{L}$ & $\leq 0.0039 \%$ & $0.01 \mathrm{~g} / \mathrm{L}$ & $5.64 \mathrm{~g} / \mathrm{L}$ & $2.72 \mathrm{~g} / \mathrm{L}$ & $5.44 \mathrm{~g} / \mathrm{L}+22.6 \mathrm{~g} / \mathrm{L}$ & $0.063 \mathrm{~g} / \mathrm{L}$ \\
\hline \multirow{5}{*}{ B. bruxellensis } & \multirow{2}{*}{ Broth } & MIC & $5 g / \mathrm{L}$ & $1.25 \mathrm{~g} / \mathrm{L}$ & $2.5 \mathrm{~g} / \mathrm{L}$ & $2.5 \mathrm{~g} / \mathrm{L}$ & $\leq 0.0039 \%$ & $0.05 \mathrm{~g} / \mathrm{L}$ & $\leq 0.71 \mathrm{~g} / \mathrm{L}$ & $0.68 \mathrm{~g} / \mathrm{L}$ & $\leq 0.043 \mathrm{~g} / \mathrm{L}+0.353 \mathrm{~g} / \mathrm{L}$ & $0.063 \mathrm{~g} / \mathrm{L}$ \\
\hline & & Biofilm & $5 \mathrm{~g} / \mathrm{L}$ & $1.25 \mathrm{~g} / \mathrm{L}$ & $2.5 \mathrm{~g} / \mathrm{L}$ & $2.5 \mathrm{~g} / \mathrm{L}$ & $\leq 0.0039 \%$ & $0.05 \mathrm{~g} / \mathrm{L}$ & $\leq 0.71 \mathrm{~g} / \mathrm{L}$ & $0.68 \mathrm{~g} / \mathrm{L}$ & $\leq 0.043 \mathrm{~g} / \mathrm{L}+0.353 \mathrm{~g} / \mathrm{L}$ & $0.063 \mathrm{~g} / \mathrm{L}$ \\
\hline & \multirow{3}{*}{ Grape Juice } & MIC & $1.25 \mathrm{~g} / \mathrm{L}$ & $2.5 \mathrm{~g} / \mathrm{L}$ & $2.5 \mathrm{~g} / \mathrm{L}$ & $1.25 \mathrm{~g} / \mathrm{L}$ & $\leq 0.0039 \%$ & $0.1 \mathrm{~g} / \mathrm{L}$ & $\leq 0.71 \mathrm{~g} / \mathrm{L}$ & $1.36 \mathrm{~g} / \mathrm{L}$ & $\leq 0.043 \mathrm{~g} / \mathrm{L}+0.353 \mathrm{~g} / \mathrm{L}$ & $0.063 \mathrm{~g} / \mathrm{L}$ \\
\hline & & MBC & $1.25 \mathrm{~g} / \mathrm{L}$ & $2.5 \mathrm{~g} / \mathrm{L}$ & $1.25 \mathrm{~g} / \mathrm{L}$ & $1.25 \mathrm{~g} / \mathrm{L}$ & $\leq 0.0039 \%$ & $0.1 \mathrm{~g} / \mathrm{L}$ & $\leq 1.42 \mathrm{~g} / \mathrm{L}$ & $2.72 \mathrm{~g} / \mathrm{L}$ & $\leq 0.043 \mathrm{~g} / \mathrm{L}+0.353 \mathrm{~g} / \mathrm{L}$ & $0.063 \mathrm{~g} / \mathrm{L}$ \\
\hline & & Biofilm & $20 \mathrm{~g} / \mathrm{L}$ & $10 \mathrm{~g} / \mathrm{L}$ & $20 \mathrm{~g} / \mathrm{L}$ & $20 \mathrm{~g} / \mathrm{L}$ & $\leq 0.0039 \%$ & $0.1 \mathrm{~g} / \mathrm{L}$ & $\leq 1.42 \mathrm{~g} / \mathrm{L}$ & $0.68 \mathrm{~g} / \mathrm{L}$ & $2.72 \mathrm{~g} / \mathrm{L}+11.3 \mathrm{~g} / \mathrm{L}$ & $0.17 \mathrm{gL}$ \\
\hline \multirow{5}{*}{ Z. baili } & \multirow{2}{*}{ Broth } & MIC & $\leq 0.625 \mathrm{~g} / \mathrm{L}$ & $1.25 \mathrm{~g} / \mathrm{L}$ & $1.25 \mathrm{~g} / \mathrm{L}$ & $1.25 \mathrm{~g} / \mathrm{L}$ & $\leq 0.0039 \%$ & $0.025 \mathrm{~g} / \mathrm{L}$ & $\leq 1.42 \mathrm{~g} / \mathrm{L}$ & $0.34 \mathrm{~g} / \mathrm{L}$ & $\leq 0.043 \mathrm{~g} / \mathrm{L}+0.353 \mathrm{~g} / \mathrm{L}$ & $0.063 \mathrm{~g} / \mathrm{L}$ \\
\hline & & MBC & $1.25 \mathrm{~g} / \mathrm{L}$ & $2.5 \mathrm{gL}$ & $5 \mathrm{~g} / \mathrm{L}$ & $2.5 \mathrm{~g} / \mathrm{L}$ & $\leq 0.0039 \%$ & $0.1 \mathrm{~g} / \mathrm{L}$ & $\leq 1.42 \mathrm{~g} / \mathrm{L}$ & $0.34 \mathrm{~g} / \mathrm{L}$ & $\leq 0.043 \mathrm{gL}+0.353 \mathrm{~g} / \mathrm{L}$ & $0.063 \mathrm{gL}$ \\
\hline & \multirow{3}{*}{ Grape Juice } & MIC & $\leq 0.625 \mathrm{~g} / \mathrm{L}$ & $1.25 \mathrm{~g} / \mathrm{L}$ & $1.25 \mathrm{~g} / \mathrm{L}$ & $1.25 \mathrm{~g} / \mathrm{L}$ & $\leq 0.0039 \%$ & $0.025 \mathrm{~g} / \mathrm{L}$ & $\leq 1.42 \mathrm{~g} / \mathrm{L}$ & $0.34 \mathrm{~g} / \mathrm{L}$ & $\leq 0.043 \mathrm{~g} / \mathrm{L}+0.353 \mathrm{~g} / \mathrm{L}$ & $0.063 \mathrm{~g} / \mathrm{L}$ \\
\hline & & MBC & $2.5 \mathrm{~g} / \mathrm{L}$ & $5 \mathrm{~g} / \mathrm{L}$ & $5 \mathrm{~g} / \mathrm{L}$ & $5 \mathrm{~g} / \mathrm{L}$ & $\leq 0.0039 \%$ & $0.1 \mathrm{~g} / \mathrm{L}$ & $2.82 \mathrm{~g} / \mathrm{L}$ & $1.36 \mathrm{~g} / \mathrm{L}$ & $\leq 0.043 \mathrm{~g} / \mathrm{L}+0.353 \mathrm{~g} / \mathrm{L}$ & $1.25 \mathrm{mg} / \mathrm{L}$ \\
\hline & & Biofilm & $10 \mathrm{~g} / \mathrm{L}$ & $20 \mathrm{~g} / \mathrm{L}$ & $2.5 \mathrm{~g} / \mathrm{L}$ & $10 \mathrm{~g} / \mathrm{L}$ & $\leq 0.0039 \%$ & $0.1 \mathrm{~g} / \mathrm{L}$ & $11.3 \mathrm{~g} / \mathrm{L}$ & $1.36 \mathrm{~g} / \mathrm{L}$ & $2.72 \mathrm{~g} / \mathrm{L}+11.3 \mathrm{~g} / \mathrm{L}$ & $0.063 \mathrm{~g} / \mathrm{L}$ \\
\hline \multicolumn{3}{|c|}{$\begin{array}{l}\text { Manufacturer's Reccomended } \\
\text { Concentration }\end{array}$} & $10-20 \mathrm{~g} / \mathrm{L}$ & $10-20 \mathrm{~g} / \mathrm{L}$ & $10 \cdot 20 \mathrm{~g} / \mathrm{L}$ & $10-20 \mathrm{~g} / \mathrm{L}$ & $17 \%(v / v)^{*}$ & $0.1-0.2 \mathrm{~g} / \mathrm{L}$ & $11.3-33.9 \mathrm{~g} / \mathrm{L}$ & $2.72 \mathrm{~g} / \mathrm{L}$ & $\begin{array}{c}2.72 \mathrm{~g} / \mathrm{L}\left(\mathrm{KHSO}_{4}\right)+11.3 \mathrm{~g} / \mathrm{L} \\
\left(\mathrm{H}_{2} \mathrm{O}_{2}\right)\end{array}$ & $0.1-0.2 \mathrm{~g} / \mathrm{L}$ \\
\hline
\end{tabular}

both the microbe inoculum and peracetic acid solution directly into the quenching media. Cells were stained and analyzed as described above.

\section{Results and discussion}

\subsection{MIC/MBC and biofilm assay}

The MIC/MBC assay is a well-established, highthroughput method for determining the minimum concentration of antifungal agents required to inactivate yeast cells. This method is commonly used in clinical heath settings but is adapted here to assess conditions relevant to wineries for the first time. The assay is typically performed with Mueller-Hinton broth $(\mathrm{MH})$, a media specifically designed for the purpose of antimicrobial susceptibility testing of nonfastidious organisms [14]. Preliminary analysis of growth rate for the three yeast species used in this experiment demonstrated that the cells did not reach sufficient population density to produce a visible haze in well plates after 24 hours incubation, a requirement for assessment of the MIC/MBC. YM broth was substituted for MH broth for this reason. Fifty percent grape juice medium was used to replicate the winery environment and to assess whether MIC/MBC values depend on the growth and test media. Results for the minimum inhibitory and minimum biocidal concentrations of the cleaning and sanitizing agents are summarized in Table 4 along with manufacturer's recommended concentration for comparison. All analysis was performed in triplicate and repeated if any differences were seen in MBC culture results. MIC values were determined as concentrations that resulted in average absorbance measurements of $\mathrm{OD}_{600 \mathrm{~nm}}=0.1$ or greater, a level which produces a light visible haze in the well plate by visual inspection [14]. Raw absorbance values and standard deviation are presented in Supplementary.

There are several key takeaways from Table 4. First, the test medium clearly influences the concentrations required to inactivate or inhibit the yeast. For the MIC/MBC assay, in $56.7 \%$ of cases higher concentrations were required to inactivate microorganisms in $50 \%$ grape juice medium, compared to $30.0 \%$ of cases where the concentrations were equal and only $14.3 \%$ where the broth was higher. A possible explanation for the grape juice generally requiring higher chemical concentrations to inactivate cells could be attributed to the increased dissolved species content of grape juice, which can react with the antimicrobials and slow or reduce their efficacy. Possible explanations for higher concentrations required in YM broth could be related to $\mathrm{pH}$, as the broth has higher $\mathrm{pH}$ than grape juice and may counteract the efficacy of some cleaning and sanitizing chemicals. Biofilms are commonly reported to have increased resistance to antimicrobial agents versus planktonic suspensions of the same organism. In $40 \%$ of trials greater concentrations were required to inactivate biofilm populations, however in $36.7 \%$ of trials lower concentrations were required for the biofilms so the theory of increased resistance is not well supported here. One possible explanation is due to the protocol, in which the biofilms are rinsed several times to remove chemical residues prior to sonication and sampling. If the chemical treatment can dislodge the biofilm from the surface, cells would not be recovered regardless of their viability. Cases in which the biofilm was inactivated at lower chemical concentrations than corresponding planktonic populations could be the result of this effect, which may be an inconsistency in the method applied as a measure of concentrations required for inactivation. In future study the method can be adapted to ensure biofilms are not physically detached by the treatment to be captured for culture analysis.

Manufacturers suggest concentrations for effective application of their proprietary cleaning and sanitizing products. Data for tests used to determine these recommended concentrations are not readily available, however, and are frequently conducted using organisms not relevant to wine production settings. The manufacturer's suggested concentrations used in this experiment are either derived from the manufacturers themselves (for proprietary products) or taken as a consensus of several sources $[1,4,16,17]$. While in many cases a treatment was successful in inactivating some combination of organism and physiology at much reduced concentration, the treatments that resulted in complete inactivation of all specimens were in the range of manufacturer 
suggestions with the exception of the complex proprietary blend containing EDTA, carbonate blend, and quaternary ammonium compounds (QUAT), which was effective below one tenth of recommended concentration. This is an interesting result, as the potential for chemical savings using this product are large. The potassium bisulfate formulation, based on the green sanitation scheme presented in Boulton, 2015 [3] was effective at or below the recommended concentration for all cases except Saccharomyces cerevisiae. S. cerevisiae required substantially higher concentrations than suggested. This trend underlies the importance of the microbe species used in testing, since E. coli was used to develop recommendations in the study and is clearly not representative of Saccharomyces behavior.

It is important to emphasize the difference between cleaning and sanitizing agents in practical terms as products are separately marketed for cleaning and sanitation purposes with differing intended usage. Cleaning typically refers to the removal of soils, where the goal of sanitation is microbial inactivation. However, in this experiment products marketed as cleaners (potassiumand sodium hydroxide-based formulations, and the QUAT/EDTA mixture) effectively inactivate microbial populations at recommended concentrations. While there is no substitution for a separate sanitation cycle, it is important to acknowledge that the microbial population is at least somewhat diminished prior to beginning the sanitation cycle when designing protocols. The combined effect of a cleaner and sanitizer in succession may act as a form of hurdle technology and be more effective than the sum of the cleaner and sanitizer action separately [5]. The numbers presented in this experiment are for use of the chemicals alone, so it is possible that lower concentrations may be effective for cleaner-sanitizer combination treatments in the practical winery environment. Additional study is required to determine if this could be a feasible strategy for reducing chemical use.

Winemakers are not able to predict the spoilage microorganisms present inside tanks, so it is prudent to use chemicals at rates that are effective for all conditions. Cleaning and sanitizing chemistries should be applied at recommended concentrations, where effective, for quality assurance. The treatments that required higher concentrations than suggested should be used with caution. In all cases, wineries should independently validate their chosen cleaning and sanitizing protocols using cell culture techniques.

It should be noted the biofilm susceptibility assay is commonly assessed using a specialized microtiter plate specifically designed for assessing antimicrobial susceptibility of biofilm-forming bacteria (called the MBEC assay) [18]. This device is available in plainor fluorapatite-coated plates to facilitate cell adhesion. In preliminary trials the three yeast species used in this experiment failed to form consistent, reproducible adherent colonies with plain or coated plates using the MBEC assay. For this reason, the MIC/MBC procedure was instead modified to include biofilm formation as described in Joseph, Kumar, and Bisson, 2007 [13] to assess biofilm susceptibility to antimicrobial agents.

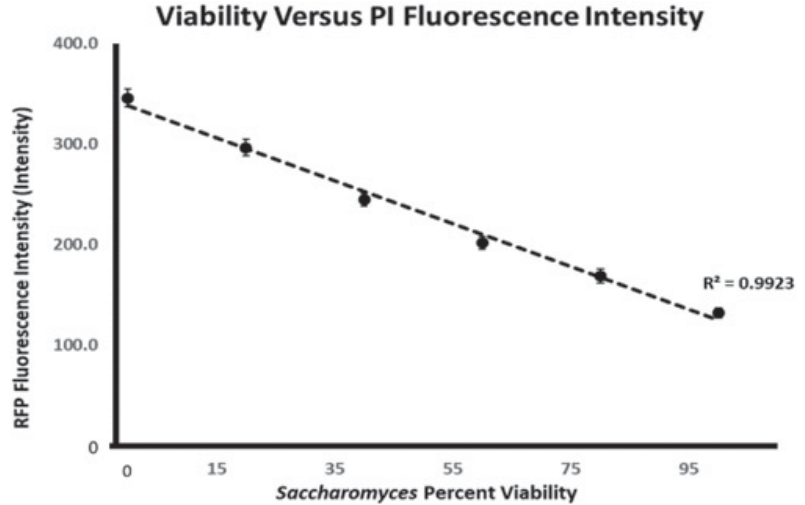

Figure 1. Demonstration of RFP intensity as a measure of Saccharomyces viability.

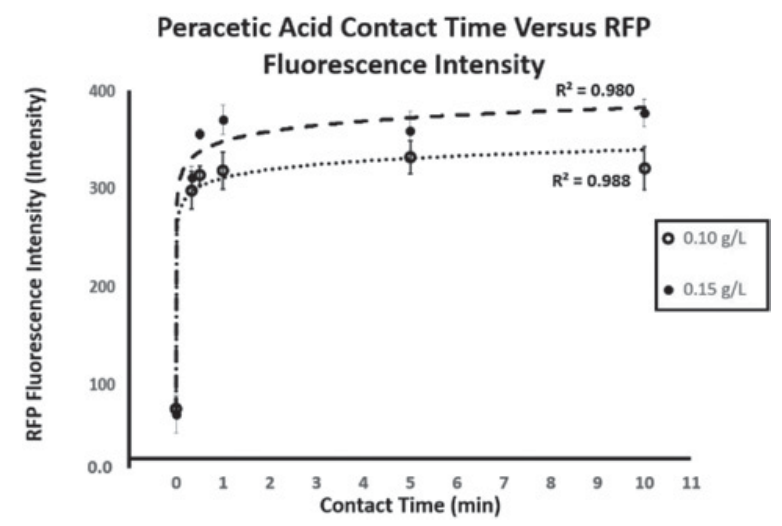

Figure 2. Killing curves for Saccharomyces cerevisiae exposed to two concentrations of peracetic acid.

Fluorescent staining is a natural complement to the MIC/MBC assay. The MIC/MBC assay provides a simple method for determining minimum effective chemical concentrations, but requires chemical agents to have 24 hours contact time with microbes. This contact time is not feasible in winery protocols where minimizing cleaning time is critical. Fluorescence spectroscopy can be employed in short-interval time-kill experiments and provides a basis for assessing the minimum contact time needed for the concentrations obtained in the MIC/MBC assay. While traditional plate count data is still the gold standard in time-kill experiments, results can take days or even weeks for fastidious organisms [19]. Fluorescent stain data is rapidly obtained, requiring only minutes for scans using a microplate reader. Fluorescent staining with propidium iodide is a well-established method, but the selective exclusion of propidium iodide depends on the loss of cellular membrane integrity and control [20]. Therefore, only a limited number of cleaning and sanitizing agents can be used that have modes of action primarily affecting membrane permeability. As such, the proprietary blend of EDTA, carbonates, and QUAT effective in the MIC/MBC was not able to be assessed by this method. Peracetic acid is a natural choice for these criteria, however. Peracetic acid was used at two concentrations: the minimum concentration required to inactivate all three yeast in planktonic and biofilm populations $(0.1 \mathrm{~g} / \mathrm{L})$ and a slightly higher concentration $(0.15 \mathrm{~g} / \mathrm{L})$ to assess whether there is a significant tradeoff 
Table 5. Plate count results for peracetic acid.

\begin{tabular}{|c|c|c|c|c|c|c|c|c|}
\hline \multicolumn{9}{|c|}{$0.10 \mathrm{~g} / \mathrm{L}$ peracetic acid } \\
\hline Contact Time (min) & \multicolumn{6}{|c|}{ Cell Count $\left({ }^{*} 10^{\wedge}-1 \mathrm{CFU} / \mathrm{mL}\right)$} & Average & Standard \\
\hline 0 & 370 & 450 & 530 & 520 & 600 & 660 & 521.67 & 103.42 \\
\hline 0.3333 & 58 & 79 & 64 & 112 & 80 & 62 & 75.83 & 19.92 \\
\hline 0.5 & 31 & 11 & 18 & 28 & 55 & 9 & 25.33 & 17.00 \\
\hline 1 & 1 & 10 & 0 & 0 & 8 & 3 & 3.67 & 4.32 \\
\hline 5 & 0 & 0 & 0 & 0 & 0 & 0 & 0.00 & 0.00 \\
\hline 10 & 0 & 0 & 0 & 0 & 0 & 0 & 0.00 & 0.00 \\
\hline \multicolumn{9}{|c|}{$0.15 \mathrm{~g} / \mathrm{L}$ peracetic acid } \\
\hline Contact Time (min) & \multicolumn{6}{|c|}{ Cell Count $\left({ }^{*} 10^{\wedge}-1 \mathrm{CFU} / \mathrm{mL}\right)$} & Average & $\begin{array}{l}\text { Standard } \\
\text { Deviation }\end{array}$ \\
\hline 0 & 550 & 500 & 570 & 390 & 540 & 520 & 511.67 & 64.32 \\
\hline 0.3333 & 66 & 49 & 81 & 72 & 60 & 59 & 64.50 & 11.15 \\
\hline 0.5 & 20 & 12 & 24 & 8 & 25 & 21 & 18.33 & 6.83 \\
\hline 1 & 0 & 5 & 7 & 9 & 0 & 8 & 4.83 & 3.97 \\
\hline 5 & 0 & 0 & 0 & 0 & 0 & 0 & 0.00 & 0.00 \\
\hline 10 & 0 & 0 & 0 & 0 & 0 & 0 & 0.00 & 0.00 \\
\hline
\end{tabular}

Table 6. Raw fluorescence intensity data for peracetic acid trials.

\begin{tabular}{|c|c|c|c|c|c|c|c|c|}
\hline \multicolumn{9}{|c|}{$0.10 \mathrm{~g} / \mathrm{L}$ peracetic acid } \\
\hline Contact Time & \multicolumn{6}{|c|}{ Fluorescence Intensity } & Average & St. dev \\
\hline 0 & 59.16 & 66.37 & 64.18 & 77.79 & 49.19 & 61.94 & 63.11 & 9.36 \\
\hline 0.3333 & 312.38 & 279.4 & 322.51 & 298.04 & 272.5 & 279.35 & 294.03 & 20.28 \\
\hline 0.5 & 302.9 & 298.23 & 327.07 & 308.58 & 310.8 & 313.06 & 310.11 & 9.92 \\
\hline 1 & 321.41 & 300.95 & 323.77 & 317.4 & 285.29 & 342.8 & 315.27 & 19.88 \\
\hline 5 & 320.82 & 318.36 & 356.54 & 314.27 & 319.81 & 345.95 & 329.29 & 17.47 \\
\hline 10 & 349.84 & 295.56 & 314.4 & 311.53 & 294.62 & 338.88 & 317.47 & 22.60 \\
\hline \multicolumn{9}{|c|}{$0.15 \mathrm{~g} / \mathrm{L}$ peracetic acid } \\
\hline $\begin{array}{l}\text { Contact Time } \\
(\min )\end{array}$ & \multicolumn{6}{|c|}{ Fluorescence Intensity } & Average & St. dev \\
\hline 0 & 56.17 & 61.24 & 45.55 & 76.12 & 53.42 & 49.12 & 56.94 & 10.86 \\
\hline 0.3333 & 322.45 & 282.84 & 297.54 & 311.03 & 337.73 & 294.38 & 307.66 & 20.15 \\
\hline 0.5 & 357.33 & 364.84 & 350.46 & 349.98 & 359.26 & 341.31 & 353.86 & 8.32 \\
\hline 1 & 386.5 & 351.81 & 368.67 & 348.79 & 389.81 & 368.89 & 369.08 & 16.99 \\
\hline 5 & 378.23 & 347.83 & 359.17 & 339.8 & 335.05 & 384.03 & 357.35 & 20.23 \\
\hline 10 & 371.25 & 375.99 & 358.57 & 353.9 & 417.51 & 381.75 & 376.50 & 22.67 \\
\hline
\end{tabular}

between minimizing chemical concentrations and the contact time required to be effective.

First, the ability of the RFP/GFP protocol to act as a proxy for cellular viability was validated using ethanol and a gradient of live versus dead cells inactivated via suspension in $70 \%$ ethanol. Analysis was performed in triplicate. Linear regression analysis was performed using embedded Microsoft Linear Regression Algorithm. Results are displayed in Fig. 1, which illustrates two key points. First, the RFP alone acts as a reliable proxy for cellular viability with a high degree of linearity $(R=$ 0.99). The GFP, which is supposed to stain all cells independent of viability varies substantially in these data (data not shown). Previous studies have indicated that the GFP and RFP can interact and compete for binding sites [21], however there isn't a clear trend for cells with higher
RFP fluorescence to exhibit lower GFP intensities so this may not be the explanation here. In this case, inclusion of GFP in the analysis would diminish the ability of the RFP to reliably indicate cellular viability. For this reason, RFP intensity was used alone in the analysis of peracetic acid inactivation rates while the staining protocol remained unchanged for consistency of the method.

Samples for time-kill analysis were taken over a range of 10 minutes. RFP intensity are given in Fig. 2 and plate count data are given in Table 5. All runs were performed in triplicate. Average values and standard deviation of replicates is displayed. These results indicate that Saccharomyces populations were effectively inactivated after five minutes contact time at both concentrations. RFP fluorescence intensity and plate count trends are both well described by logarithmic relationships as assessed by 
Table 7. Absorbance averages for MIC determination.

\begin{tabular}{|c|c|c|c|c|c|c|c|c|c|c|c|}
\hline \multicolumn{12}{|c|}{ S. cerevisiae broth } \\
\hline $\mathrm{NaOH}$ & $\begin{array}{l}\mathrm{NaOH}- \\
\text { blend }\end{array}$ & $\mathrm{KOH}$ & KOH-blend & $\begin{array}{l}\text { Na-K- Carbonate } \\
\text { blend, EDTA }\end{array}$ & Peracetic Acid & $\mathrm{H} 2 \mathrm{O} 2$ & KHSO4 & $\begin{array}{c}\mathrm{KHSO}_{\mathrm{H} 2 \mathrm{O}}+ \\
\end{array}$ & $\mathrm{ClO} 2$ & $\begin{array}{l}\text { grouth } \\
\text { check }\end{array}$ & $\begin{array}{l}\text { sterility } \\
\text { check }\end{array}$ \\
\hline 0.00 & 0.00 & 0.00 & 0.00 & 0.00 & 0.00 & 0.01 & 0.02 & 0.01 & 0.01 & & \\
\hline 0.00 & 0.00 & 0.00 & 0.00 & 0.00 & 0.01 & 0.00 & 0.02 & 0.01 & 0.01 & & \\
\hline 0.00 & 0.00 & 0.00 & 0.00 & 0.00 & 0.00 & 0.00 & 0.03 & 0.00 & 0.05 & 0.68 & 0.00 \\
\hline 0.00 & 0.00 & 0.00 & 0.00 & 0.00 & 0.00 & 0.00 & 0.09 & 0.00 & 0.22 & 0.61 & 0.00 \\
\hline 0.00 & 0.00 & 0.00 & 0.00 & 0.00 & 0.00 & 0.00 & 0.09 & 0.00 & 0.33 & 0.86 & 0.00 \\
\hline 0.00 & 0.00 & 0.01 & 0.00 & 0.10 & 0.02 & 0.01 & 0.11 & 0.00 & 0.49 & 0.68 & 0.00 \\
\hline 0.01 & 0.01 & 0.03 & 0.00 & 0.10 & 0.07 & 0.01 & 0.50 & 0.00 & 0.69 & 0.83 & 0.00 \\
\hline 0.19 & 0.41 & 0.17 & 0.02 & 0.00 & 0.57 & 0.01 & 0.61 & 0.01 & 0.62 & 0.61 & 0.00 \\
\hline \multicolumn{12}{|c|}{ S. cerevisiae $50 \%$ grape juice } \\
\hline $\mathrm{NaOH}$ & $\begin{array}{l}\mathrm{NaOH}- \\
\text { blend }\end{array}$ & $\mathrm{KOH}$ & KOH-blend & $\begin{array}{l}\text { Na-K-Carbonate } \\
\text { blend, EDTA }\end{array}$ & Peracetic Acid & $\mathrm{H} 2 \mathrm{O} 2$ & KHSO4 & $\begin{array}{l}\mathrm{KHSO} 4+ \\
\mathrm{H} 2 \mathrm{O} 2\end{array}$ & $\mathrm{ClO} 2$ & $\begin{array}{l}\text { grounth } \\
\text { check }\end{array}$ & $\begin{array}{l}\text { sterility } \\
\text { check }\end{array}$ \\
\hline 0.02 & 0.00 & 0.01 & 0.01 & 0.00 & 0.03 & 0.03 & 0.02 & 0.02 & 0.02 & & \\
\hline 0.03 & 0.00 & 0.03 & 0.00 & 0.00 & 0.03 & 0.03 & 0.02 & 0.02 & 0.02 & & \\
\hline 0.04 & 0.01 & 0.02 & 0.00 & 0.00 & 0.02 & 0.02 & 0.04 & 0.02 & 0.03 & 0.88 & 0.00 \\
\hline 0.02 & 0.02 & 0.01 & 0.00 & 0.20 & 0.03 & 0.02 & 0.03 & 0.02 & 0.43 & 0.93 & 0.00 \\
\hline 0.01 & 0.04 & 0.02 & 0.00 & 0.00 & 0.03 & 0.01 & 0.03 & 0.03 & 0.76 & 1.00 & 0.00 \\
\hline 0.02 & 0.14 & 0.08 & 0.00 & 0.00 & 0.55 & 0.02 & 0.11 & 0.02 & 0.68 & 0.88 & 0.00 \\
\hline 0.17 & 0.77 & 0.71 & 0.11 & 0.00 & 1.03 & 0.02 & 1.24 & 0.02 & 0.79 & 0.88 & 0.00 \\
\hline 0.79 & 0.99 & 1.07 & 0.19 & 0.10 & 0.95 & 0.02 & 1.49 & 0.01 & 0.81 & 1.03 & 0.00 \\
\hline \multicolumn{12}{|c|}{ B bruxellensis broth } \\
\hline $\mathrm{NaOH}$ & $\begin{array}{l}\mathrm{NaOH}- \\
\text { blend }\end{array}$ & $\mathrm{KOH}$ & KOH-blend & $\begin{array}{l}\text { Na-K-Carbonate } \\
\text { blend, EDTA }\end{array}$ & Peracetic Acid & $\mathrm{H} 2 \mathrm{O} 2$ & KHSO4 & $\begin{array}{l}\mathrm{KHSO} 4+ \\
\mathrm{H} 2 \mathrm{O} 2\end{array}$ & $\mathrm{ClO} 2$ & $\begin{array}{l}\text { grounth } \\
\text { check }\end{array}$ & $\begin{array}{c}\text { sterility } \\
\text { check }\end{array}$ \\
\hline 0.01 & 0.03 & 0.01 & 0.02 & 0.00 & 0.02 & 0.04 & 0.01 & 0.01 & 0.03 & & \\
\hline 0.00 & 0.02 & 0.02 & 0.00 & 0.00 & 0.02 & 0.01 & 0.01 & 0.00 & 0.02 & & \\
\hline 0.02 & 0.03 & 0.03 & 0.01 & 0.01 & 0.03 & 0.00 & 0.00 & 0.00 & 0.01 & 0.94 & 0.00 \\
\hline 0.02 & 0.02 & 0.01 & 0.02 & 0.00 & 0.00 & 0.00 & 0.02 & 0.01 & 0.49 & 0.68 & 0.00 \\
\hline 0.03 & 0.03 & 0.02 & 0.04 & 0.04 & 0.01 & 0.00 & 0.04 & 0.01 & 0.48 & 0.64 & 0.00 \\
\hline 0.37 & 0.03 & 0.04 & 0.04 & 0.02 & 0.33 & 0.00 & 0.51 & 0.02 & 0.48 & 0.50 & 0.00 \\
\hline 0.28 & 0.07 & 0.22 & 0.26 & 0.00 & 0.53 & 0.00 & 0.79 & 0.02 & 0.51 & 0.64 & 0.00 \\
\hline 0.46 & 0.26 & 0.22 & 0.25 & 0.01 & 0.55 & 0.02 & 0.89 & 0.01 & 0.46 & 0.58 & 0.00 \\
\hline \multicolumn{12}{|c|}{ B. bruxellensis $50 \%$ grape juice } \\
\hline $\mathrm{NaOH}$ & $\begin{array}{l}\mathrm{NaOH}- \\
\text { blend }\end{array}$ & $\mathrm{KOH}$ & KOH-blend & $\begin{array}{l}\text { Na- K-Carbonate } \\
\text { blend, EDTA }\end{array}$ & Peracetic Acid & $\mathrm{H} 2 \mathrm{O} 2$ & KHSO4 & $\begin{array}{c}\mathrm{KHSO} 4+ \\
\mathrm{H} 2 \mathrm{O} 2\end{array}$ & $\mathrm{ClO} 2$ & $\begin{array}{l}\text { grounth } \\
\text { check }\end{array}$ & $\begin{array}{c}\text { sterility } \\
\text { check }\end{array}$ \\
\hline 0.01 & 0.00 & 0.00 & 0.00 & 0.02 & 0.01 & 0.01 & 0.02 & 0.03 & 0.02 & & \\
\hline 0.02 & 0.00 & 0.00 & 0.00 & 0.02 & 0.00 & 0.02 & 0.00 & 0.01 & 0.02 & & \\
\hline 0.02 & 0.00 & 0.00 & 0.00 & 0.03 & 0.01 & 0.03 & 0.03 & 0.02 & 0.01 & 1.32 & 0.00 \\
\hline 0.01 & 0.00 & 0.00 & 0.00 & 0.00 & 0.00 & 0.03 & 0.04 & 0.02 & 0.12 & 1.30 & 0.00 \\
\hline 0.02 & 0.00 & 0.00 & 0.00 & 0.02 & 0.21 & 0.02 & 0.16 & 0.02 & 0.53 & 1.12 & 0.00 \\
\hline 0.01 & 0.00 & 0.00 & 0.00 & 0.07 & 0.22 & 0.02 & 1.10 & 0.03 & 0.91 & 1.31 & 0.00 \\
\hline 0.03 & 0.16 & 0.11 & 0.03 & 0.00 & 121 & 0.03 & 1.15 & 0.02 & 1.09 & 1.10 & 0.00 \\
\hline 0.12 & 1.15 & 1.23 & 0.95 & 0.09 & 1.44 & 0.03 & 1.06 & 0.03 & 1.07 & 1.21 & 0.00 \\
\hline \multicolumn{12}{|c|}{ Z. baili broth } \\
\hline $\mathrm{NaOH}$ & $\begin{array}{l}\mathrm{NaOH}- \\
\text { blend }\end{array}$ & $\mathrm{KOH}$ & КОH-blend & $\begin{array}{l}\text { Na-K-Carbonate } \\
\text { blend, EDTA }\end{array}$ & Peracetic Acid & $\mathrm{H} 2 \mathrm{O} 2$ & KHSO4 & $\begin{array}{c}\mathrm{KHSO} 4+ \\
\mathrm{H} 2 \mathrm{O} 2\end{array}$ & $\mathrm{ClO} 2$ & $\begin{array}{l}\text { grounth } \\
\text { check }\end{array}$ & $\begin{array}{l}\text { sterility } \\
\text { check }\end{array}$ \\
\hline 0.03 & 0.03 & 0.02 & 0.04 & 0.02 & 0.03 & 0.03 & 0.02 & 0.02 & 0.03 & & \\
\hline 0.09 & 0.00 & 0.04 & 0.04 & 0.00 & 0.03 & 0.03 & 0.02 & 0.02 & 0.02 & & \\
\hline 0.03 & 0.01 & 0.03 & 0.04 & 0.00 & 0.03 & 0.03 & 0.02 & 0.01 & 0.01 & 0.29 & 0.00 \\
\hline 0.02 & 0.03 & 0.02 & 0.02 & 0.00 & 0.04 & 0.03 & 0.01 & 0.01 & 0.11 & 0.47 & 0.00 \\
\hline 0.02 & 0.04 & 0.02 & 0.02 & 0.02 & 0.04 & 0.02 & 0.02 & 0.01 & 0.23 & 0.96 & 0.00 \\
\hline 0.02 & 0.04 & 0.02 & 0.02 & 0.07 & 0.31 & 0.03 & 0.04 & 0.01 & 0.39 & 0.59 & 0.00 \\
\hline 0.04 & 0.04 & 0.03 & 0.04 & 0.00 & 0.50 & 0.03 & 0.34 & 0.02 & 0.49 & 0.58 & 0.00 \\
\hline 0.03 & 0.91 & 0.58 & 0.21 & 0.09 & 0.50 & 0.03 & 0.54 & 0.03 & 0.93 & 0.61 & 0.00 \\
\hline \multicolumn{12}{|c|}{ Z. baili $50 \%$ grape juice } \\
\hline $\mathrm{NaOH}$ & $\begin{array}{l}\mathrm{NaOH}- \\
\text { blend }\end{array}$ & $\mathrm{KOH}$ & KOH-blend & $\begin{array}{c}\text { Na-K-Carbonate } \\
\text { blend, EDTA }\end{array}$ & Peracetic Acid & $\mathrm{H} 2 \mathrm{O} 2$ & KHSO4 & $\begin{array}{c}\mathrm{KHSO} 4+ \\
\mathrm{H} 2 \mathrm{O} 2\end{array}$ & $\mathrm{ClO} 2$ & $\begin{array}{l}\text { grounth } \\
\text { checle }\end{array}$ & $\begin{array}{l}\text { sterility } \\
\text { check }\end{array}$ \\
\hline 0.02 & 0.00 & 0.02 & 0.00 & 0.02 & 0.02 & 0.02 & 0.02 & 0.02 & 0.02 & & \\
\hline 0.04 & 0.00 & 0.02 & 0.00 & 0.02 & 0.02 & 0.01 & 0.01 & 0.00 & 0.01 & & \\
\hline 0.03 & 0.00 & 0.01 & 0.00 & 0.00 & 0.01 & 0.02 & 0.01 & 0.00 & 0.01 & 0.29 & -0.01 \\
\hline 0.02 & 0.02 & 0.01 & 0.00 & 0.00 & 0.02 & 0.03 & 0.01 & 0.00 & 0.13 & 0.47 & -0.01 \\
\hline 0.02 & 0.02 & 0.01 & 0.01 & 0.02 & 0.03 & 0.03 & 0.01 & 0.00 & 0.24 & 0.59 & -0.01 \\
\hline 0.01 & 0.03 & 0.01 & 0.01 & 0.00 & 0.31 & 0.02 & 0.04 & 0.01 & 0.36 & 0.54 & -0.01 \\
\hline 0.03 & 0.03 & 0.02 & 0.02 & 0.03 & 0.48 & 0.03 & 0.39 & 0.02 & 0.48 & 0.97 & -0.01 \\
\hline 0.02 & 0.48 & 0.57 & 0.20 & 0.04 & 0.48 & 0.01 & 0.93 & 0.01 & 0.52 & 0.59 & -0.01 \\
\hline
\end{tabular}


Table 8. Standard deviations of MIC absorbance values.

\begin{tabular}{|c|c|c|c|c|c|c|c|c|c|c|c|}
\hline \multicolumn{12}{|c|}{ S. cerevisiae broth } \\
\hline $\mathrm{NaOH}$ & $\mathrm{NaOH}$-blend & KOH & KOH-blend & $\begin{array}{l}\text { Na- K-Carbonsto } \\
\text { blend, EDTA }\end{array}$ & Peracetic Acid & $\mathrm{H} 202$ & KHSO4 & $\underset{\mathrm{H}}{\mathrm{KHSO}}+$ & $\mathrm{ClO} 2$ & grourth check & sterility check \\
\hline 0.003 & 0.003 & 0.083 & 0.001 & 0.018 & 0.015 & 0.007 & 0.007 & 0.002 & 0.004 & & \\
\hline 0.002 & 0.001 & 0.023 & 0.001 & 0.060 & 0.013 & 0.000 & 0.004 & 0.005 & 0.002 & & \\
\hline 0.002 & 0.002 & 0.003 & 0.002 & 0.045 & 0.008 & 0.002 & 0.005 & 0.005 & 0.069 & 0.383 & 0.004 \\
\hline 0.001 & 0.002 & 0.001 & 0.001 & 0.010 & 0.007 & 0.002 & 0.002 & 0.002 & 0.094 & 0.182 & 0.005 \\
\hline 0.002 & 0.001 & 0.002 & 0.001 & 0.002 & 0.008 & 0.002 & 0.002 & 0.003 & 0.073 & 0.374 & 0.004 \\
\hline 0.004 & 0.006 & 0.001 & 0.002 & 0.088 & 0.003 & 0.008 & 0.003 & 0.002 & 0.191 & 0.272 & 0.004 \\
\hline 0.010 & 0.040 & 0.002 & 0.005 & 0.121 & 0.008 & 0.008 & 0.235 & 0.001 & 0.069 & 0.241 & 0.003 \\
\hline 0.129 & 0.186 & 0.003 & 0.102 & 0.193 & 0.010 & 0.009 & 0.155 & 0.003 & 0.194 & 0.233 & 0.002 \\
\hline \multicolumn{12}{|c|}{ S. cerevisiae $50 \%$ grape juice } \\
\hline $\mathrm{NaOH}$ & $\mathrm{NaOH}-b l e n d$ & коH & KOH-blend & $\begin{array}{l}\text { Na- K-Carbonsto } \\
\text { bleud, EDTA }\end{array}$ & Perscetic Acid & $\mathrm{H} 202$ & KHSO4 & $\underset{\mathrm{H} 2 \mathrm{OHSO}}{\mathrm{KHO}}$ & $\mathrm{ClO} 2$ & grourth check & sterility check \\
\hline 0.006 & 0.003 & 0.005 & 0.022 & 0.007 & 0.037 & 0.003 & 0.002 & 0.002 & 0.004 & & \\
\hline 0.019 & 0.002 & 0.005 & 0.026 & 0.001 & 0.001 & 0.003 & 0.005 & 0.006 & 0.001 & 0.136 & 0.000 \\
\hline 0.017 & 0.002 & 0.011 & 0.004 & 0.008 & 0.024 & 0.530 & 0.008 & 0.009 & 0.019 & 0.057 & 0.001 \\
\hline 0.013 & 0.002 & 0.003 & 0.004 & 0.011 & 0.004 & 0.012 & 0.005 & 0.006 & 0.114 & 0.050 & 0.001 \\
\hline 0.007 & 0.003 & 0.004 & 0.025 & 0.011 & 0.042 & 0.010 & 0.011 & 0.011 & 0.187 & 0.029 & 0.001 \\
\hline 0.003 & 0.010 & 0.003 & 0.041 & 0.494 & 0.010 & 0.014 & 0.007 & 0.009 & 0.063 & 0.058 & 0.001 \\
\hline 0.013 & 0.098 & 0.099 & 0.054 & 0.044 & 0.022 & 0.013 & 0.047 & 0.010 & 0.062 & 0.082 & 0.001 \\
\hline 0.193 & 0.015 & 0.133 & 0.204 & 0.122 & 0.029 & 0.003 & 0.097 & 0.002 & 0.077 & 0.081 & 0.004 \\
\hline \multicolumn{12}{|c|}{ B bruxellensis broth } \\
\hline $\mathrm{NaOH}$ & $\mathrm{NaOH}$-blend & КоH & KOH-blend & $\begin{array}{l}\text { Na- K- Carbonsto } \\
\text { blend, EDTA }\end{array}$ & Perscetic Acid & $\mathrm{H} 202$ & KHSO4 & $\underset{\mathrm{H}}{\mathrm{KHO} 02}$ & $\mathrm{ClO}_{2}$ & grourth check & sterility check \\
\hline 0.002 & 0.000 & 0.085 & 0.001 & 0.007 & 0.002 & 0.014 & 0.001 & 0.001 & 0.001 & & \\
\hline 0.001 & 0.004 & 0.001 & 0.002 & 0.011 & 0.003 & 0.002 & 0.001 & 0.000 & 0.002 & & \\
\hline 0.001 & 0.001 & 0.002 & 0.001 & 0.000 & 0.006 & 0.014 & 0.001 & 0.001 & 0.010 & 0.003 & 0.001 \\
\hline 0.001 & 0.001 & 0.001 & 0.001 & 0.006 & 0.004 & 0.010 & 0.001 & 0.002 & 0.007 & 0.019 & 0.005 \\
\hline 0.001 & 0.001 & 0.002 & 0.004 & 0.002 & 0.003 & 0.023 & 0.001 & 0.001 & 0.004 & 0.031 & 0.005 \\
\hline 0.001 & 0.003 & 0.002 & 0.001 & 0.002 & 0.000 & 0.023 & 0.003 & 0.003 & 0.010 & 0.044 & 0.003 \\
\hline 0.002 & 0.001 & 0.001 & 0.001 & 0.001 & 0.004 & 0.069 & 0.014 & 0.005 & 0.035 & 0.018 & 0.001 \\
\hline 0.002 & 0.002 & 0.002 & 0.001 & 0.001 & 0.000 & 0.019 & 0.254 & 0.003 & 0.023 & 0.021 & 0.002 \\
\hline \multicolumn{12}{|c|}{ B. bruxellensis $50 \%$ grape juice } \\
\hline $\mathrm{NaOH}$ & $\mathrm{NaOH}$-blend & КоH & KOH-blend & $\begin{array}{l}\text { Na- K-Carbonsto } \\
\text { blend, EDTA }\end{array}$ & Peracetic Acid & $\mathrm{H} 202$ & KHSO4 & $\underset{\mathrm{H} 202}{\mathrm{KHSO} 4+}$ & $\mathrm{ClO} 2$ & grourth check & sterility check \\
\hline 0.002 & 0.004 & 0.037 & 0.004 & 0.028 & 0.051 & 0.007 & 0.005 & 0.001 & 0.003 & & \\
\hline 0.001 & 0.002 & 0.122 & 0.005 & 0.032 & 0.003 & 0.017 & 0.004 & 0.005 & 0.004 & & \\
\hline 0.002 & 0.002 & 0.016 & 0.014 & 0.016 & 0.018 & 0.013 & 0.005 & 0.005 & 0.002 & 0.057 & 0.001 \\
\hline 0.002 & 0.006 & 0.007 & 0.015 & 0.008 & 0.010 & 0.010 & 0.004 & 0.002 & 0.002 & 0.069 & 0.003 \\
\hline 0.004 & 0.003 & 0.007 & 0.010 & 0.008 & 0.021 & 0.004 & 0.018 & 0.002 & 0.198 & 0.303 & 0.002 \\
\hline 0.006 & 0.001 & 0.007 & 0.008 & 0.007 & 0.010 & 0.008 & 0.074 & 0.004 & 0.262 & 0.072 & 0.003 \\
\hline 0.004 & 0.067 & 0.018 & 0.119 & 0.744 & 0.007 & 0.004 & 0.033 & 0.008 & 0.049 & 0.145 & 0.001 \\
\hline 0.015 & 0.108 & 0.187 & 0.085 & 0.243 & 0.020 & 0.006 & 0.049 & 0.005 & 0.006 & 0.083 & 0.005 \\
\hline \multicolumn{12}{|c|}{ Z. baili broth } \\
\hline $\mathrm{NaOH}$ & $\mathrm{NaOH}$-blend & коH & KOH-blend & $\begin{array}{l}\text { Na- K-Carbonsto } \\
\text { blend, EDTA }\end{array}$ & Perscetic Acid & $\mathrm{H} 202$ & KHSO4 & $\begin{array}{l}\text { KHSO4 + } \\
\text { H2O2 }\end{array}$ & $\mathrm{ClO} 2$ & grourth check & sterility chock \\
\hline 0.001 & 0.009 & 0.029 & 0.002 & 0.004 & 0.000 & 0.013 & 0.007 & 0.004 & 0.008 & & \\
\hline 0.003 & 0.009 & 0.028 & 0.014 & 0.011 & 0.014 & 0.013 & 0.015 & 0.009 & 0.005 & & \\
\hline 0.004 & 0.009 & 0.016 & 0.013 & 0.010 & 0.022 & 0.014 & 0.015 & 0.009 & 0.015 & 0.016 & 0.002 \\
\hline 0.001 & 0.010 & 0.011 & 0.021 & 0.023 & 0.007 & 0.016 & 0.013 & 0.009 & 0.016 & 0.083 & 0.004 \\
\hline 0.003 & 0.008 & 0.014 & 0.020 & 0.009 & 0.019 & 0.012 & 0.014 & 0.009 & 0.007 & 0.041 & 0.002 \\
\hline 0.001 & 0.005 & 0.012 & 0.025 & 0.099 & 0.019 & 0.016 & 0.012 & 0.008 & 0.013 & 0.070 & 0.005 \\
\hline 0.006 & 0.007 & 0.017 & 0.017 & 0.146 & 0.020 & 0.013 & 0.005 & 0.013 & 0.013 & 0.011 & 0.004 \\
\hline 0.005 & 0.019 & 0.013 & 0.099 & 0.167 & 0.044 & 0.000 & 0.045 & 0.010 & 0.048 & 0.033 & 0.003 \\
\hline \multicolumn{12}{|c|}{ Z. baili $50 \%$ grape juice } \\
\hline $\mathrm{NaOH}$ & $\mathrm{NaOH}$-blend & KOH & KOH-blend & $\begin{array}{l}\text { Na- K-Carbonsto } \\
\text { bleud, EDTA }\end{array}$ & Perscetic Acid & $\mathrm{H} 202$ & $\mathrm{KHSO4}$ & $\begin{array}{c}\mathrm{KHSO4}+ \\
\mathrm{H} 202\end{array}$ & $\mathrm{ClO} 2$ & grourth check & sterility check \\
\hline 0.001 & 0.008 & 0.029 & 0.002 & 0.004 & 0.008 & 0.013 & 0.007 & 0.004 & 0.008 & & \\
\hline 0.003 & 0.009 & 0.028 & 0.014 & 0.011 & 0.014 & 0.013 & 0.015 & 0.009 & 0.005 & & \\
\hline 0.004 & 0.009 & 0.016 & 0.013 & 0.010 & 0.022 & 0.014 & 0.015 & 0.009 & 0.015 & 0.016 & 0.002 \\
\hline 0.001 & 0.010 & 0.011 & 0.021 & 0.023 & 0.007 & 0.016 & 0.013 & 0.009 & 0.016 & 0.085 & 0.004 \\
\hline 0.003 & 0.008 & 0.014 & 0.020 & 0.009 & 0.019 & 0.012 & 0.014 & 0.009 & 0.007 & 0.041 & 0.002 \\
\hline 0.001 & 0.008 & 0.012 & 0.025 & 0.099 & 0.019 & 0.016 & 0.012 & 0.008 & 0.013 & 0.070 & 0.005 \\
\hline 0.006 & 0.007 & 0.017 & 0.017 & 0.146 & 0.020 & 0.013 & 0.005 & 0.013 & 0.013 & 0.011 & 0.004 \\
\hline 0.005 & 0.019 & 0.013 & 0.089 & 0.167 & 0.044 & 0.000 & 0.045 & 0.010 & 0.048 & 0.033 & 0.003 \\
\hline
\end{tabular}


Microsoft Logarithmic Regression Analysis. These results suggest first-order, or apparent first order inactivation kinetics, similar to patterns observed in classic enzyme inactivation or thermal inactivation models [21,22]. The close correlation between plate count and fluorescence data support the reliability of RFP as a method for tracking cellular viability. Given these results, it could be suggested that effective winery sanitation with peracetic acid may be completed with 5 minutes contact time at $0.1 \mathrm{~g} / \mathrm{L}$ concentration. In real-world situations, wineries will encounter limitations in the ability of cleaning apparatuses to provide consistent chemical contact with contaminated surfaces, so sanitation cycles may be longer than this optimized contact time. Wineries should independently test and validate any changes to cleaning and sanitizing protocols to determine treatment efficacy.

\section{Conclusion}

In this experiment the MIC/MBC assay was used to optimize the concentrations of common winery cleaning and sanitizing agents required to inactivate three common yeast species in planktonic physiologies. A modified version of the assay was used to investigate the difference in concentrations required to inactivate cells in biofilm physiologies. While certain combinations of organism, physiology, and chemical were effective below recommended concentrations, only a complex mixture of EDTA, carbonates, and QUAT was totally effective at reduced concentrations. Dual-channel fluorescent staining using propidium iodide and SYBR green 1 was validated as a proxy for cellular viability, and then used to assess the contact time required to inactivate Saccharomyces cerevisiae at two different concentrations of peracetic acid. Five minutes of contact time appears to be effective for inactivating Saccharomyces cerevisiae populations at the minimal effective concentration $(3.8 \mathrm{mg} / \mathrm{L})$. Wineries should use these simple tests to validate the efficacy of their own protocols and minimize chemical usage and contact time to optimize production.

\section{References}

[1] K.C. Fugelsang, C.G. Edwards, Wine Microbiology: Practical Applications and Procedures (Springer Science + Business Media, LLC, 2007)

[2] K.L. Christ, R.L. Burritt, J. Clean. Prod. 53, 232 (2013)
[3] R. Boulton, Advances in Wine Research, edited by S.B. Ebeler, G. Sacks, S. Vidal, P. Winterhalter (Oxford University Press, 2015), p. 379

[4] F.L. Duarte, A. Lopez, M.F. Alemao, R. Santos, S. Canas, Ciência e Técnica Vitivinícola 26, 45 (2011)

[5] M. Solis, D.M. Gadoury, R.W. Worobo, Ciência e Técnica Vitivinícola 31, 41 (2016)

[6] M. Tristezza, et al., Ann. Microbiol. 60, 549 (2010)

[7] J.M. Zuehlke, B. Petrova, C.G. Edwards, Annu. Rev. Food Sci. Technol. 4, 57 (2012)

[8] T.F.C. Mah, G.A. O’Toole, Trends Microbiol. 9, 34 (2001)

[9] I. Wiegand, K. Hilpert, R.E.W Hancock, Nat. Protoc. 3, 163 (2008)

[10] R.N. Tiballi, J.E. Spiegel, L.T. Zarins, C.A. Kauffman, Diagn. Microbiol. Infect. Dis. 23, 135 (1995)

[11] J. Hašek, Yeast Protocol (Humana Press, 2006), p. 85

[12] T. Zhang, H.H.P. Fang, Biotechnol. Lett. 26, 989 (2004)

[13] C.M.L. Joseph, G. Kumar, E. Su, L.F. Bisson, Am. J. Enol. Vitic. 58, 373 (2007)

[14] CLSI, Reference Method for Broth Dilution Antifungal Susceptibility Testing of Yeasts?; Approved Standard - Second Edition NCCLS standards and guidelines 22 (2008)

[15] J. Feng, T. Wang, S. Zhang, W. Shi, Y. Zhang, PLoS One 9, e111809 (2014)

[16] Wine Institute, Sanitation Guide for Wineries (San Francisco, 1961)

[17] L. Leistner, Hurdle Technologies?: Combination Treatments for Food Stability, Safety, and Quality (New York, Kluwer Academic/Plenum Publishers, 2002)

[18] T. Christaki, C. Tzia, Food Control 13, 503 (2002)

[19] J.H. Jorgensen, M.J. Ferraro, Clin. Infect. Dis. 49, 1749 (2009)

[20] S. Hoffmann, et al., Front. Cell. Infect. Microbiol. 8, 43 (2018)

[21] H.M. Davey, P. Hexley, Environ. Microbiol. 13, 163 (2011)

[22] M. Berney, F. Hammes, F. Bosshard, H.U. Weilenmann, T. Egli, Appl. Environ. Microbiol. 73, 3283 (2007)

[23] A. Sadana, Biotechnol. Adv. 6, 349 (1988) 